\title{
Legal matters related to structural damage in the Netherlands
}

1 Wouter Boot MSc, LLM

Civil Inspection Engineer, Iv-Infra, Sliedrecht, the Netherlands

2 Karel Terwel MSc, PhD

Director, Coenraedt B.V., Rotterdam, the Netherlands; Lecturer and researcher in structural design and safety; Faculty of Civil Engineering and Geosciences, Delft University of Technology, Delft, the Netherlands
3 Hugo Strang LLM

PhD Researcher, Dutch Institute for Construction Law, The Hague, the Netherlands
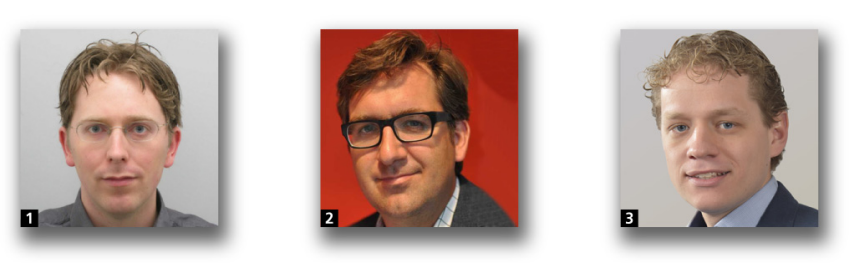

When structural damage occurs and disputes arise, forensic engineers have to search for the causes of this damage to find out who can be held liable for it. Legal systems must provide an adequate, reasonable, effective and complete way to solve these disputes. Each country has its own system with advantages and disadvantages. This paper provides an overview of the Dutch legal system concerning liability, dispute resolution and insurances. These themes will be illustrated by quantitative research data, a comparison between the Netherlands and England and by discussing advantages and disadvantages of rules, such as reasonableness and influences on structural safety. In this way, the aim is to share knowledge and contribute to the discussion regarding the legal and judicial framework relating to structural damage.

\section{Introduction}

The building industry is prone to errors for at least two reasons. First, every construction project is unique (location, structure, external conditions such as soil conditions), and therefore methods are less standardised than in the manufacturing industry (Hinze, 1993). Second, the realisation of a construction project is a collective effort of many parties with their various backgrounds and perspectives. Communication errors, and a lack of collaboration and coordination between parties, are not uncommon (Terwel, 2014).

Errors can result in defects and defects may lead to disputes. Solving these disputes can pose technical as well as legal challenges: technical challenges occur because the forensic engineer has to determine the cause(s) of the structural damage. Failure investigation shows that defects often result from a combination of errors (Boot, 2010; Schneider and Matousek, 1976). Legal challenges lie in answering questions like: Should the engineer be liable for this error? If so, for what part of the damage? Should the contractor have warned the engineer when he noticed the design error? What is the most appropriate institute to settle the dispute?

Answering these questions can be difficult. Therefore, it is important to have an adequate, reasonable, effective and complete legal and judicial framework to solve these disputes. Each country has its own system with advantages and disadvantages. This paper will discuss the Dutch legal and judicial framework when structural damage occurs. In the Netherlands, there have been many discussions about the system, especially distribution of liability among parties. To give the discussion an international dimension, some comparisons between the Netherlands and England will be given. As will become apparent, there are some interesting differences between those countries.

After a short introduction to the Dutch legal and organisational framework, the paper will cover a selection of legal matters related to structural damage. The paper concerns the situation where a traditional contract (design and construction are separated) is drawn up and will employ the latest versions of the most commonly used 
general terms and conditions in the Netherlands, namely De Nieuwe Regeling (DNR) and Uniforme Administratieve Voorwaarden (UAV). Liability for design and construction errors is included, because these are predominantly the cause for structural damage in the Netherlands (Terwel et al., 2014). Details like specific exceptions on general rules are beyond the scope of this paper. It should be noted that this paper is about liability of engineering companies and contractors, not about liability of their employees (like structural engineers), who only in specific cases can personally be held liable. Criminal law, public law, the law of evidence and subcontracting are not included.

\section{Dutch legal and organisational framework}

\subsection{Civil as opposed to common law}

A common law system (as in England) is based on legal precedents. The Netherlands has a civil law legal system, which is based on a written code. Written codes are more extensive than the statutes in England. In the Netherlands, courts have to apply the written codes and fill in possible gaps. They are not obliged to follow earlier judgements, although often courts will judge in line with established Supreme Court jurisprudence. The Dutch Civil Code is an eclectic product which took more than 40 years to write and was largely finished in 1992.

\subsection{Contract as opposed to tort}

In England, there is a distinction between contract-based and tort-based liability. Assuming there is a contract between claimant and defendant, the claimant has to decide which one to choose or chose both (concurrent liability). The choice depends of several factors, like limitation periods and the type of loss (physical damage, personal injury or pure economic, such as loss of profit). In the Netherlands a similar distinction between contract and tort is present. However, the contractual parties cannot choose between the two liabilities. Only when there is no contractual relationship between two parties (e.g. between employer and subcontractor), will the injured party try to claim that the other party committed a 'tortious act' and therefore can be held liable.

\subsection{Project delivery systems}

Depending on the desired extent of collaboration between parties and distribution of responsibilities, the employer will choose between several types of project delivery systems. In addition to design-bid-build (referred to as the traditional model; the design and the construction are separated, see Figure 4 in the following section), the design-build method is an option (the design and the construction are integrated, see Figure 5 in the following section). The design-bid-build method is more commonly used for residential, commercial and industrial construction, whereas design-build models (and affiliate methods which include maintenance and operation after delivery) are more commonly used in civil engineering projects, such as viaducts, bridges and tunnels (Stichting Aanbestedingsinstituut Bouw and Infra, 2013). To give an impression of the Dutch construction industry, some characteristics concerning turnover are shown in Figures 1, 2 and 3.

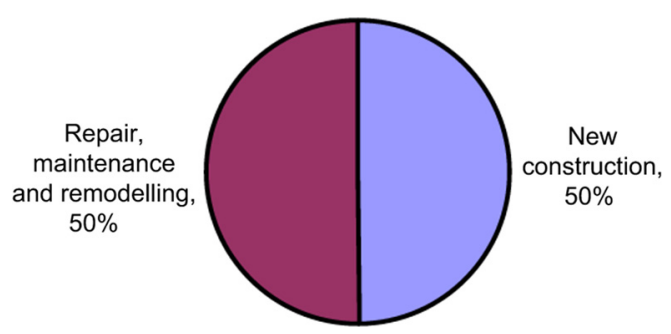

Figure 1. Distribution of yearly turnover in 2012 by type of work (Koning and Schep, 2012)

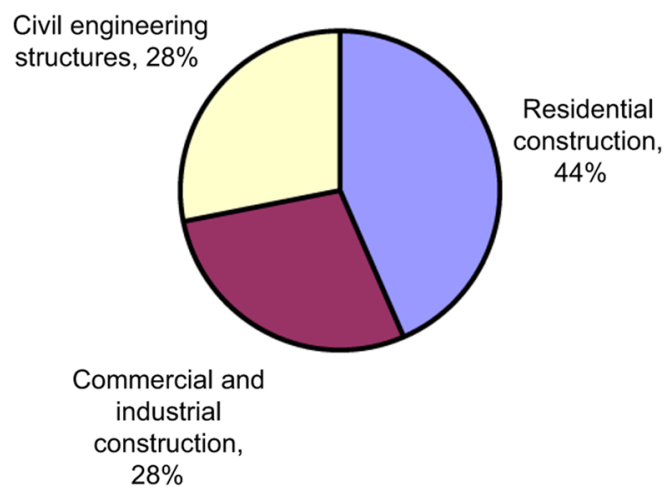

Figure 2. Distribution of yearly turnover (new construction) in 2012 by type of construction (Koning and Schep, 2012)

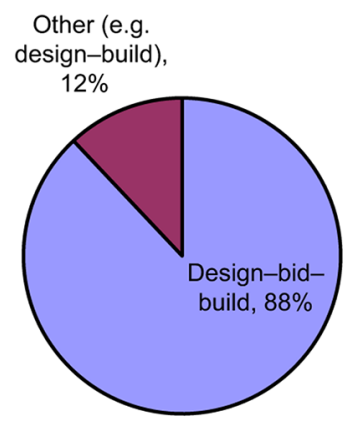

Figure 3. Distribution of methods of procurement in 2012 (Stichting Aanbestedingsinstituut Bouw and Infra, 2013)

\subsection{General terms and conditions}

The Dutch Civil Code contains general contract law including liability rules, but only some rules that are specifically made for the legal relationships between employers, their contractors and design professionals. To fill these gaps in legislation for the construction industry, general terms and conditions were made by a collaboration of Dutch building organisations from all sides of the building industry, such as government departments and 


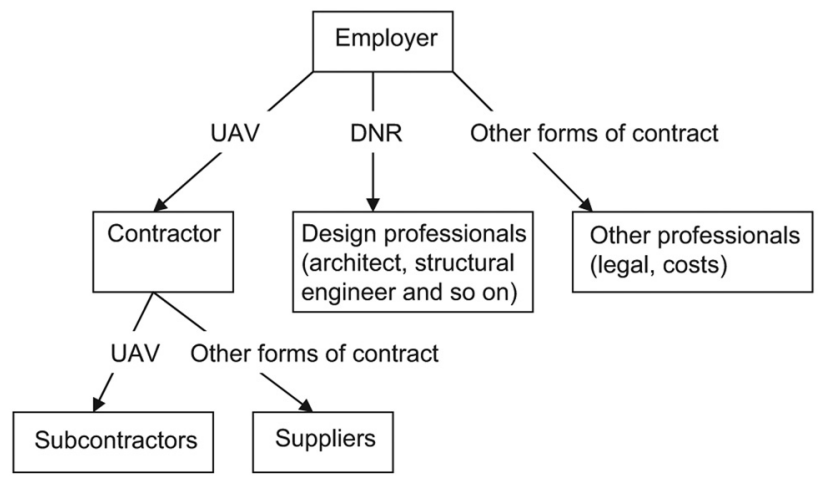

Figure 4. Schematic diagram of construction parties for design-bid-build

professional associations. As in England, in the Netherlands it is common to use general terms and conditions in the construction industry. It would be time consuming and costly to negotiate a completely new contract each time. General terms and conditions comply with and are complementary to the Dutch Civil Code. However, some rules deviate from the Code. This is allowed, because most rules that do exist in the Code about these parties, are not binding when parties agree to deviate from them. Only a few rules are mandatory. General terms and conditions include rules about tasks, liability, dispute resolution, intellectual property, payment and other obligations. Parties can agree to modify these rules to their liking.

Depending on the chosen project delivery system, one or more general terms and conditions are available to use (see Figures 4 and 5). They are updated every 5-20 years. There are not as many general terms and conditions as in England. Nowadays, the most used general terms and conditions are the UAV and the DNR (BNA and NLingenieurs, 2011a). The most recent versions are the UAV 2012 and the DNR 2011. The UAV is used in the case of the design-bid-build method and the UAV-GC (most recent version dates from 2005) in the case of the design-build method.

\subsection{Obligations of parties}

In the DNR and the UAV obligations of parties are stated. Some important ones in the scope of this paper are mentioned in this subsection. The employer must behave to the consultant (structural engineer) as 'a good and careful client' (clause 12.1 DNR), supply correct information in time (clause 12.2 DNR) and warn the consultant if he notices or should have been aware of a shortcoming in the advice of the consultant (clause 12.4 DNR). The tasks of the consultant (structural engineer) are to 'advise' (meaning the result of his activities), to carry out the assignment in a proper and careful manner (clause 11.2 DNR), to warn over shortcomings in data and decisions of the employer (clause 11.10 DNR) and to be covered by a professional indemnity insurance (clause 11.3 DNR). In addition, the consultant has (or can arrange to have) the necessary knowledge and

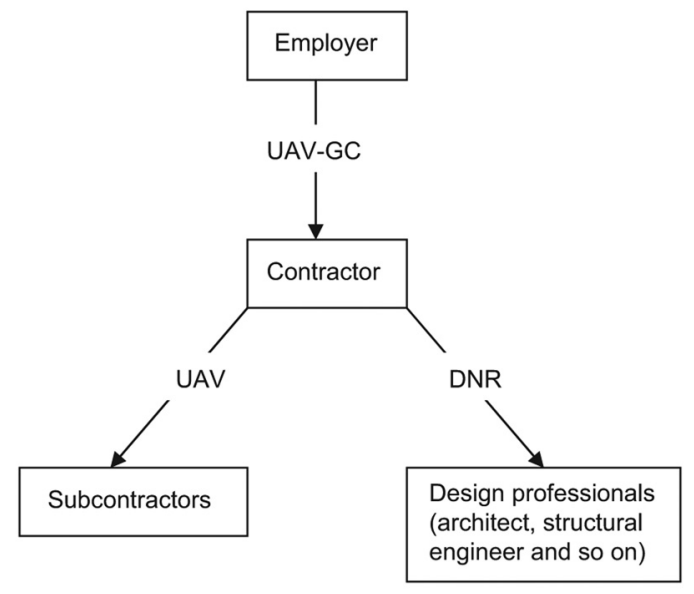

Figure 5. Schematic diagram of construction parties for bid-build

capacity for proper fulfilment of the commission at their disposal (clause 11.1 DNR).

The employer has to pay the contractor ( $\$ 40$ clause $1 \mathrm{UAV}$ ), supply drawings and other data to the contractor ( $\$ 5$ clause 1.c. UAV). Furthermore, the employer can choose whether or not to appoint an agent. If they do, the agent has to superintend the execution ( $\$ 3$ clause $6 \mathrm{UAV}$ ). The contractor has to execute the work ( $\$ 6$ clause $1 \mathrm{UAV}$ ), carry out instructions of the employer ( $\$ 6$ clause 2 UAV) and warn for obvious errors in structures, working methods and instructions ( $\$ 6$ clause $14 \mathrm{UAV}$ ).

\section{Liability of structural engineers}

\subsection{Culpable faults}

As explained in Section 2, the DNR is the main important source of liability rules for the structural engineer. The DNR states that the consultant (structural engineer) is liable for 'culpable faults'. A culpable fault is defined as 'a shortcoming accountable to guilt, or by virtue of the law, legal action or according to generally accepted opinions comes at the expense of the debtor'. Under generally accepted opinions is to be understood: 'a shortcoming which a well and conscientiously operating consultant or client under the relevant circumstances and with regard to a normal attentiveness and with respect to the consultant: equipped with the professional knowledge and means required for the commission - should have been able and ought to have avoided'. So, while in England the liability test is about the jurisprudence established in 'reasonable skill and care' (Lupton, 2013), in the Netherlands it is according to the DNR concerning 'well and conscientiously operating', 'normal attentiveness' and 'equipped with the professional knowledge'.

The DNR does not give any guidance on interpreting these criteria. It therefore falls to a court to decide whether an error is a culpable fault or not. Dutch case law can give some insight in this. However, it should be noted that it is difficult to derive general rules from 
case law about which case is or is not culpable. The court bases its decisions on the particular facts and circumstances of the case. Design errors like incorrect schematisation of the structure, inadequate analysis of geotechnical survey when designing the foundation, or failure to study relevant literature can result in a culpable fault.

\subsection{Duty to warn}

When a structural engineer is responsible for supervising the construction and detects an error, they have to give a warning for that error. If the structural engineer is responsible for reviewing design work of another design professional, this warning must also be given. In those cases, there will be a task (supervising and/or reviewing) formulated in the contract, for example by filling in a supplement to the DNR whereby agreement is reached over the specific task. Independent of the specified tasks, for errors in information and/or data of the employer, the structural engineer has to warn. The DNR states that

The consultant has an obligation to warn the client if information and/or data provided by or on behalf of the client or decisions taken by or on behalf of the client manifestly contain such shortcomings or show such deficiencies that he would act in defiance of standards of reasonableness and fairness should he proceed thereupon with the fulfilment of the commission.

Also, the explanatory addendum of the DNR informs that if the employer introduces another design professional to the project and the consultant knows that this professional is not competent, the consultant has to warn over that professional (BNA and NLingenieurs, 2011b).

In addition, when a 'warning' task is not present in the contract and a structural engineer discovers a construction or design error, the engineer may have to warn too. This applies for the Netherlands, as well as England. Whether or not there is a duty to warn in these situations depends on the specific facts of the case and can be a complex decision for the court. For these situations, the present authors generally refer to a $\mathrm{PhD}$ research study carried out at the University of Amsterdam, which includes a comparison between England and the Netherlands regarding the duty of design professionals to warn (Luzak, 2012).

\subsection{Liability limitations}

From research on arbitral awards (Boot, 2010), it appears that in a small number of cases (1\%), only the structural engineer was held liable for structural damage (see Figure 6). However, the ratio between design and construction errors is about 50:50\% (Boot, 2010). This lack of balance can partly be explained by a limiting condition in the research. However, liability limitations (see Table 1) of the structural engineer will play a role. When structural damage occurs and the structural engineer has made an error, this does not automatically mean that engineer is liable for the full amount of damage or for every type of damage. Therefore liability limitations will influence whether the structural engineer can be

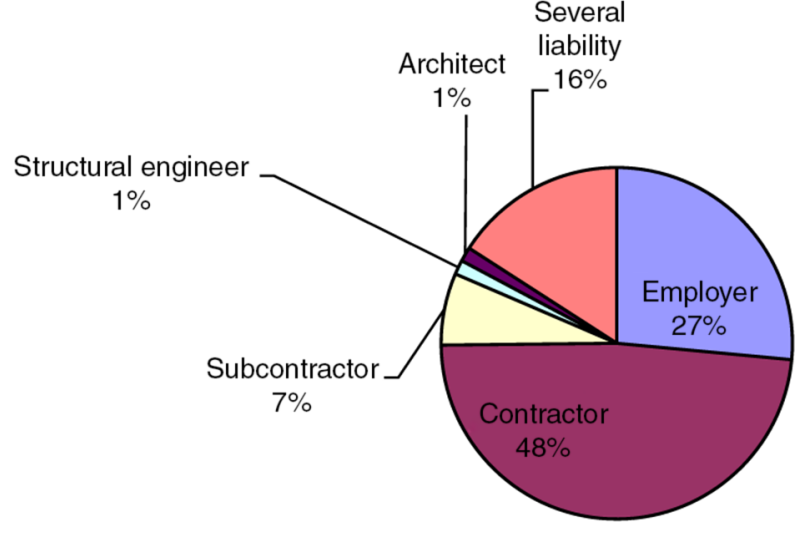

Figure 6. Liable parties after structural damage (Boot, 2010)

held liable. Liability limitations are an extensive and complex area of law. They are a matter of debate, resulting in recent changes in the DNR. The situation is comparable to England, where the law regarding limitations periods was called 'unfair, complex, uncertain and outdated' (The Law Commission, 2001).

Proponents of liability limitations argue that engineering companies should not carry the heaviest burden because of their limited financial capacity. Opponents think it is reasonable that damage is paid by the party who made the error. Also, it is believed that liability should be placed on the party who can make the best analysis of the balance between making costs and avoiding accidents, and can act upon that (Calabresi, 1970). Proponents, however, argue that there has to be a certain balance between the amount of work done and the amount of liability, which can easily be larger than the payment for the services of the structural engineer. There are also other arguments. On the one hand, a lower level of liability might lead to structural engineers accepting higher risk projects, accepting less payment for their services (VROM-Inspectie, 2008) and/or performing less quality control (Spekkink, 2009). This may lead to reduced structural safety. On the other hand, a higher level of liability might result in a lower level of innovation. Also, more liability will result in higher risk insurances that will be passed on to the employer. Furthermore, there is the question of whether mitigation of liability limitations affects the insurability of engineering companies (Chao-Duivis and Strang, 2013). Finally, considering $24 \%$ of the structural damage occurred after 5 years (see Table 1), there is the question of whether the 5-year term (see Figure 7) is reasonable.

\section{Liability of contractors}

\subsection{Hidden defects}

The general rule in Dutch construction law is that after delivery the contractor is not liable for any defects that become apparent after delivery. This rule applies under the UAV as well as the Dutch Civil Code. An exception to this rule is that the contractor remains liable after delivery for so-called hidden defects that are attributable to the contractor. 


$\begin{array}{ll}\text { Maximum } & \text { Choice by parties between (clause 15.1): } \\ \text { amount } & - \text { consultancy costs with a maximum of } € 1000000 \\ & - \text { limited to a sum equal to three times the consultancy costs with a maximum of } € 2500000 \\ & \text { Exception: if the client is a consumer the limitations shall not be lower than } € 75000 \text { (clause 15.3) } \\ \text { Type of } & \text { Only 'direct damages' (clause 14.1) } \\ \text { damage } & \text { Not liable for: business damage, loss of production loss of turnover and/or profit, depreciation of products, } \\ & \text { costs pertaining to the realisation of the object (clause 14.2) } \\ & \text { Exception: in case of evil intent or gross negligence (clause 17.5) } \\ \text { Period } & -5 \text { years from the day upon which the commission is terminated (clauses } 16.1 \text { and 16.4) } \\ & - \text { protest within due diligence after he has discovered the shortcoming or reasonably should have discovered it } \\ & \text { (clause 16.2) } \\ & - \text { the legal claim expires and is not admissible after } 2 \text { years after the written and motivated protest } \\ & \text { (clause 16.3) }\end{array}$

General exception: if the compensation is unacceptable in the given circumstances and according to the standards of reasonableness and fairness (14.6). Note: The Dutch Civil Code provides a similar rule

Table 1. Liability limitations of the DNR

Under the UAV $(\S 12)$ a hidden defect is (in short) defined as a defect which could not reasonably have been discovered by the employer or his agent during the execution or at the time of delivery. So if the employer or his agent fails to inspect the work carefully, the employer could lose his claim against the contractor. $\S 12$ UAV deviates from the Civil Code. The contractor is only discharged from liability for defects that the employer should reasonably have discovered at the time of delivery (7:758 Civil Code).

The provision regarding hidden defects in the UAV, and its interpretation by arbitrators, have been a subject of debate for many years (Van den Berg, 2013a). Proponents of the hidden defect rule in the UAV have argued that there is a balance between the contractor's duty to warn on one side and the hidden defect rule on the other (Vermeij, 2014). Another argument that is used by proponents is that the construction quality is served by careful

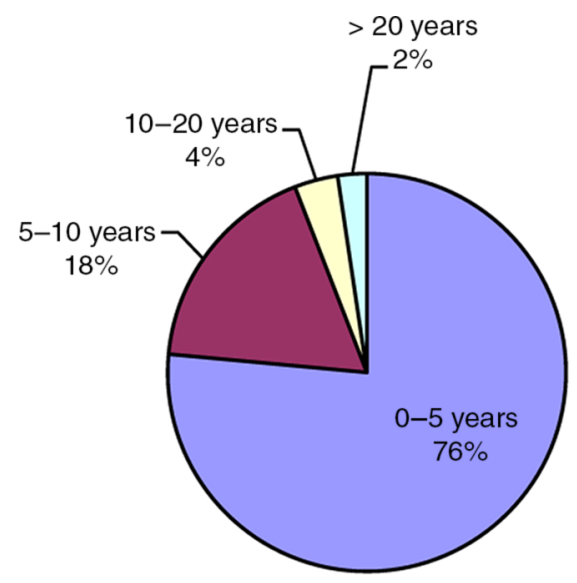

Figure 7. Number of years from delivery to structural damage (Boot, 2010) inspection by the employer or his agent (Vermeij, 2014). Opponents have argued that a hidden defect is caused by the contractor and that reduction in damages would only be justified if the employer has contributed to the damage in terms of causation (Chao-Duivis, 1991). Furthermore, inspections by the employer during the construction process are not obliged and are paid for by the employer. It would therefore not be correct that the liability of the contractor is reduced, if the employer decides to carry out inspections (Van den Berg, 2013a). This might result in employers not carrying out inspections at all.

Apart from this debate, it is a fact that a lot of case law concerns the question whether a defect was hidden or not. In this respect, it is a positive development that the Dutch government has announced legislation on hidden defects. In June 2014, a concept legislative bill was published for public consultation. In this concept bill a change of 7:758 Civil Code is proposed: the contractor will only be discharged from liability for defects that actually have been discovered at the time of delivery. According to the concept bill, it will be a provision of mandatory law. This means that the UAV (and other general terms and conditions) will have to be adjusted if the proposed 7:758 Civil Code comes unamended into force. The government expects this change will bring more balance between the position of the employer and the contractor and will reduce the amount of case law on the question of whether a defect was hidden or not.

Under English construction law, the general rule is that the contractor is not entitled to a reduction in damages because the employer or his agent failed to discover defects during the execution of the work (Furst and Ramsey, 2006). Depending on the specific terms of the contract, the issuance of a (final) certificate might give the contractor some protection (Barrett, 2008). So there is a clear difference between English construction law and current Dutch construction law. However, the Dutch law on hidden defects will 
become more comparable to English law on hidden defects, if the above-mentioned proposal is enacted.

\subsection{Duty to warn}

The employer provides the contractor with design documents such as drawings. In using these documents to determine how to execute the work, the contractor might discover design errors. When such a discovery is made, the contractor has to warn the employer. The UAV states that the contractor is liable if structures, construction methods, tools, instructions or building materials apparently contain such errors or defects, and that the contractor acts in defiance of standards of reasonableness and fairness, by starting the construction without pointing out these errors or defects to the employer. To determine the scope and extent of this duty to warn, an abundance of case law is available in the Netherlands. This in contrast to England, where it is necessary to fall back on a limited number of cases, such as Edward Lindenberg v. Joe Canning Jerome Contracting Ltd (1992), Plant Construction Plc v. Clive Adams Associates and JMH Construction Services Ltd (2000), and Aurum Investments Ltd v. Avondforce Ltd (in liquidation) (2001), when determining the scope and extent of the duty to warn (Lupton, 2013). Luzak (2012) concludes, based on a comparison between England and the Netherlands about the contractor's duty to warn, that 'English case law ... leaves us with much confusion regarding the builder's duty to warn and its scope, especially when it concerns the designer's mistakes'.

Dutch research (Boot, 2010) provides some actual figures about the duty to warn. In 27 of 151 cases with structural damage, the employer contended that the contractor was in breach of his duty to warn. Only in five of those cases did the arbitrators decide that the contractor was liable for (a part of) the damage. So, in five cases, the damage could have been avoided by acting according to the duty to warn. In addition, in three cases a warning had been given by the contractor, but the employer ignored that warning. So, in three cases, if the employer had acted upon that warning, the damage could have been avoided. It can be concluded that the duty to warn plays a role in the prevention of structural damage and therefore structural safety.

The question arises, however, of why the arbitrators in the other 19 cases concluded there was no duty to warn. A wide variety of reasons are shown: a warning would not have avoided the structural damage, the design was not unusual, only by calculations could the error have been revealed, the intended load on the foundation was not known to the contractor, or the employer was an expert so the contractor could rely on employer's expertise. In general, considering more case law about the duty to warn, two main factors can be distinguished which influence the presence of a duty to warn: the obviousness of the design error and the level of experience of the contractor (Luzak, 2012).

\section{Insurance matters}

When structural damage occurs, three types of insurances currently are the most relevant in the Netherlands: the construction all risk
(CAR) insurance, professional indemnity insurance and third-party liability insurance. CAR insurance usually covers material damage and rebuilding costs that occurred during construction. CAR insurance is generally arranged by the contractor or the client. Professional indemnity insurance is an important insurance for the structural engineer. Financial losses that are caused by attributable professional errors are covered. By bringing the amount of cover in line with the maximum claimable amount (see Table 1), financial risks can be addressed. It is possible that no damage is visible, but that, for instance, extra reinforcement is needed to recover a safe situation. Professional indemnity insurance might cover these costs, whereas CAR usually will not. Usually there is no coverage for physical injuries or for material damage to properties of third parties. For these cases structural engineers can take out a thirdparty liability insurance.

The Dutch insurance framework might change in the future. This development is related to the replacement of public into private building control in the Netherlands, which is planned for 2015. One of the possibilities for private building control is to create a system similar to that found in France (Helsloot and Schmidt, 2012). A similar change was suggested in 1988 in England by the National Economic Development Council in a report called 'Building users' insurance against latent defects' (Lupton, 2013). In France, clients and contract partners have an obligation to insure a project. Clients should have insurance for hidden defects, accompanied by the obligation of independent design and checking of construction in the case of complex structures. Contract partners, such as contractors and structural engineers, have joint and several liability for major defects and should have a professional liability insurance. Liability limitations, such as in the DNR, are not permitted. Liability can only be averted in the case of force majeure, if the defect was caused by the client or if a causal relationship between task of contract partner and the defect is not evident (Gambon, 2007). This system is believed to better protect clients in the case of hidden defects. However, drawbacks of this system are lengthy procedures and considerable costs (Gambon, 2007).

\section{Dispute resolution}

\subsection{Judicial process}

Structural damage can lead to several different legal repercussions, depending on the type of damage and decisions of the concerned parties and authorities (see Figure 8). In most cases, there will only be financial and material damage. Parties have to decide whether to settle, use alternative dispute resolution (ADR) or litigate. Each of these has its advantages and disadvantages. The choice will be made during contract negotiations and depends on costs, confidentiality, expertise required and fastness.

In case of loss of life, permanent injury or hospitalisation of employees during construction, their employer is legally obliged to notify a government organisation, called the Inspectorate SZW. The Inspectorate will investigate the accident and if necessary, notify the 


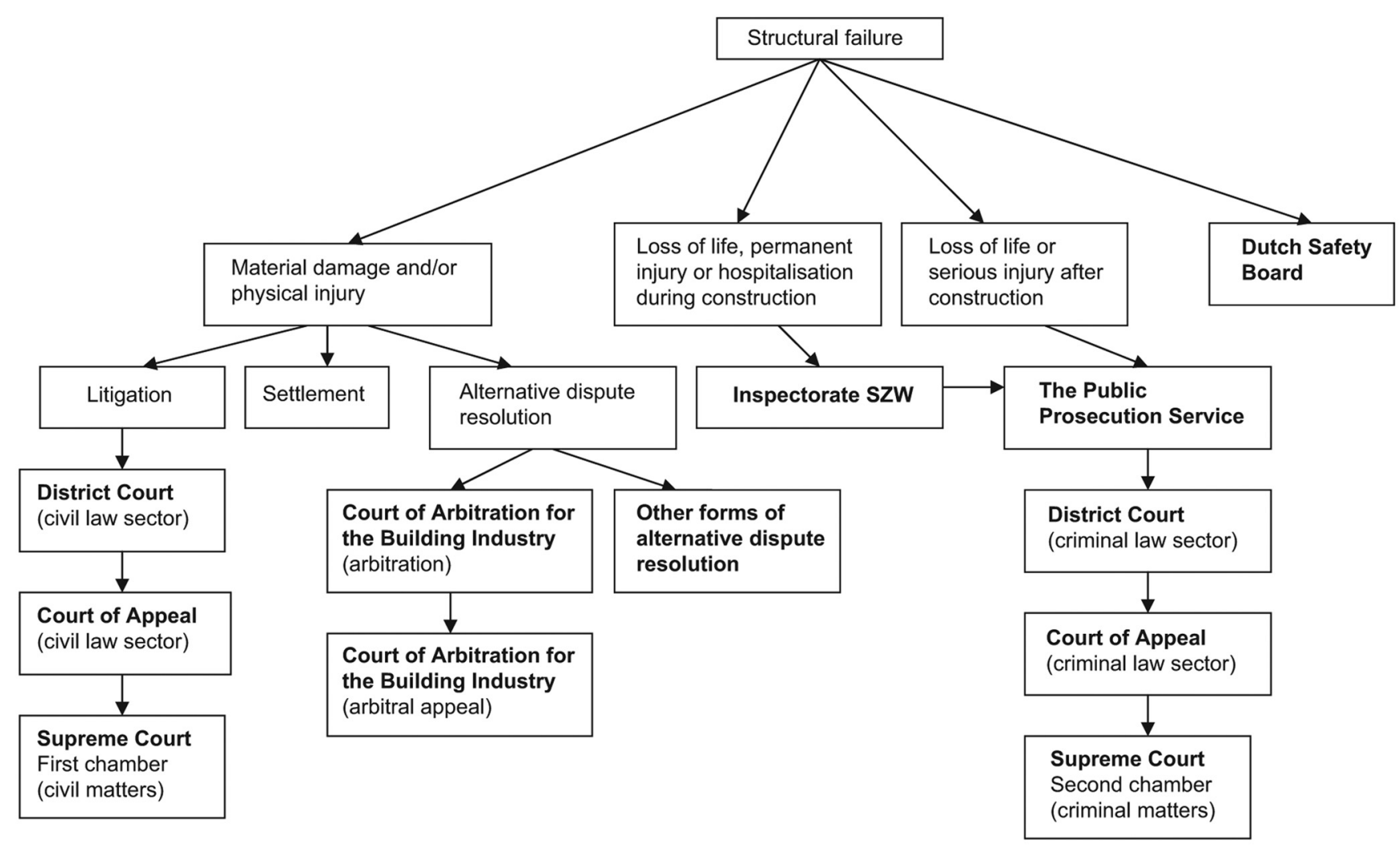

Figure 8. Judicial process after structural damage

Public Prosecution Service, which decides whether the offender must appear in a criminal court.

In addition to this criminal liability, the Dutch Safety Board can decide to conduct an investigation. This Board, similar to the Health and Safety Executive in UK, operates in different sectors, such as aviation, sea shipping and health care. The sector construction is also covered by the Dutch Safety Board, albeit to a lesser extent. The Board has, for example, investigated safety problems with falling façade slabs and two major structural collapses: the collapse of a roof of a major soccer stadium (Dutch Safety Board, 2012a) and the collapse of a utility building during construction (Dutch Safety Board, 2012b). During an investigation, the Board has a different array of considerable powers for the collection of evidence. The Board does not aim to investigate liability, but focuses on causes, consequences, safety issues and recommendations about the incident.

\subsection{Litigation}

The DNR states that disputes will be solved by litigation, unless parties decide to choose for arbitration. When litigation is chosen, a district court (or sub-district court) will deal with the case. After a decision is reached, either party can appeal at the Court of Appeal. Again, this decision can be challenged, namely by the Supreme Court. However, this court will not judge the facts of the case, but only the proper application of the law to promote legal uniformity and the development of Dutch law. There is no appeal possible for decisions of the Supreme Court.

There is no special court for (complex) construction disputes in the Netherlands, like the Technology and Construction Court (TCC) in England. This means that a judge lacks technical knowledge, and is often unfamiliar with common practices in the construction industry and general terms and conditions (Havinga et al., 2012). Therefore, in case of structural damage a judge has to call upon the assistance of an expert witness. This leads to extra costs and delays. Contrary to the party-appointed expert witnesses in England, in the Netherlands the expert witness is appointed by the judge. This is a discretionary competence.

Some drawbacks are attached to this. Without any technical knowledge, it is difficult for a judge to determine whether an expert witness is needed and which facts are within the scope of the expert witness (De Groot, 2008). The expert witness is bound to this scope and has to limit any answers to the questions asked by the judge. Because the judge has no technical knowledge, the judge often will directly follow the expert's opinion, so in fact the case is decided by the expert (Havinga et al., 2012; Van den Berg, 2013b). So, the present Dutch litigation framework is not very suitable for 'technical' construction disputes, such as cases with structural damage. The English party-appointed system may provide a solution. 
The English system, however, also has some drawbacks. One of them is that the expert witness can find themselves confronted with conflicting duties or interests: the duty to help the court and the duty to act in the best interest of the party who instructed the expert (Reynolds, 2002). Appointing a single jointcan solve this problem. However, it is still more normal for each party to engage their own experts (Buckingham, 2008).

\subsection{Arbitration}

If arbitration is chosen, the dispute will be settled by the Court of Arbitration for the Building Industry (in Dutch: Raad van Arbitrage voor de Bouw). The Court is a specific arbitration institute for construction disputes. A decision of the Court is called an arbitral award, which is legally binding on the parties and is enforceable by obtaining an exequatur at the District Court. Unlike the situation for most other arbitrations, there is a possibility of arbitral appeal at the Court. About 1000 disputes are resolved each year by in total 106 arbitrators, of whom 87 are engineers and 19 are jurists (see Raad van Arbitrage voor de Bouw (2015)). In addition, there are 16 'secretaries' at the Court, who, among other tasks, provide legal support to the arbitrators. In some special cases an arbitral award can be challenged at a District Court, namely in case of setting aside (the arbitral award does not meet some basic requirements) and revocation (in case of withholding information, deception or false documents).

Arbitrators are engineers and their assignment to a case is based on their specific knowledge, therefore often it is not necessary to appoint an expert witness and the problems mentioned in Section 6.2 are thereby avoided. In general, arbitrators themselves can assess expert reports generated by parties. Only in some cases, such as when something is outside their knowledge or when an investigation is needed, is an expert witness needed (Chao-Duivis, 2007).

Arbitration has it own challenges, however. In 2002 a $\mathrm{PhD}$ research study was published which classified the Court as an 'old boy's network' (Van Bladel, 2002). Although this research was heavily criticised for its research method and conclusions, it inflicted damage on the Court's appearance of impartiality. Nowadays, to avoid the appearance of partiality, the Court has several safeguards built into its procedures (Lampe, 2007; Van Romburgh, 2007). First, the arbitrators are put forward by organisations that represent all sides of the building industry: employers, contractors, advisors (engineers and architects) are more or less equally represented in the Court. Second, the chairman of the Court assigns arbitrators to a case, The chairman is a judge or retired judge and is appointed by The Council for the Judiciary. Third, parties can start a procedure for a District Court to substitute arbitrators. Last, all jurisprudence of the Court is published on their website.

\section{Conclusion}

Distribution of liability between parties differs in each country. In the Netherlands, liability limitations play an important role. While for structural engineers liability is limited to a maximum amount, to 'direct damage' and to limited periods of time, for contractors the limitation is present in the hidden defect rule. All these provisions are a matter of continuous debate, leading to change (liability limitations for structural engineers) or plans for change (hidden defects). Both result in a reasonable shift in liability from employers to contractors and structural engineers. Furthermore, liability can and should be used for improving structural safety. It has been shown that structural safety can benefit from a well-functioning duty to warn.

The present Dutch legal and judicial framework is working properly but constantly needs to be improved. A comparison with England and other countries can provide a broader and deeper insight for these improvements. For example, consideration may be given to installing a special court for (complex) construction disputes, like the TCC in England. Also, the use of expert witnesses should be reconsidered. There is already a plan to change the contractor's liability for hidden defects, so that it becomes more comparable to English law. However, it should be highlighted that liability, insurances, judicial matters and structural safety, are all interrelated. Together, they should result in a balanced system. It is a task for the Dutch government, by means of legislation, for the Dutch building organisations, by means of general terms and conditions, and for judges and arbitrators, by means jurisprudence, to continue improving and keep pace with changes in society and the construction industry.

\section{REFERENCES}

Aurum Investments Ltd v. Avondforce Ltd (in liquidation) (2001) 2 All ER 385; (2001) 78 Con LR 115; CILL (TCC).

Barrett K (2008) Defective Construction Work. Wiley-Blackwell, Oxford, UK, pp. 128-129.

BNA and NLingenieurs (2011a) The New Rules, Legal Relationship Client-Architect, Engineer and Consultant DNR 2011.

See www.bni.nl/ (accessed 01/08/2014).

BNA and NLingenieurs (2011b) De Nieuwe Regeling, Model Basisopdracht. Toelichting op de Rechtsverhouding Opdrachtgever - Architect, Ingenieur en Adviseur DNR 2011. See www.bni.nl, pp. 28 (in Dutch) (accessed 01/08/2014).

Boot WF (2010) Constructieve Schade: een Onderzoek naar de Constructieve Schade in Bouwwerken en de wijze Waarop weten Regelgeving een rol Spelen bij het Waarborgen van de Constructieve Veiligheid. TU Delft, Delft, the Netherlands. (in Dutch). See http://repository.tudelft.nl/view/ir/uuid\% 3Aa8526c2b-0dc0-4d82-8f69-f725ae03afd8/ (accessed 01/08/2014).

Buckingham P (2008) The effective use of experts and expert witnesses. Proceedings of Conference on Forensic Engineering: From Failure to Understanding. Thomas Telford, London, UK, pp. 544-553.

Calabresi G (1970) The Costs of Accidents: A Legal and Economic Analysis. Yale University Press, New Haven, USA.

Chao-Duivis MAB (1991) Informatie- en mededelingsplichten: een causaliteitsprobleem. Tijdschrift Bouwrecht 1991(2): 81-94. (in Dutch). 
Chao-Duivis MAB (2007) De rol van deskundigen bij de vaststelling van schade in het bouwrecht. Nederlands Tijdschrift voor Burgerlijk Recht 70: 484 (in Dutch).

Chao-Duivis MAB and Strang HPCW (2013) Naar een Andere Verdeling van Verantwoordelijkheid in de Bouw. Instituut voor Bouwrecht, The Hague, the Netherlands, pp. 114 (in Dutch). See www.rijksoverheid.nl/bestanden/documenten-en-publicaties/ rapporten/2013/02/01/naar-een-andere-verdeling-vanverantwoordelijkheid-in-de-bouw/naar-een-andere-verdelingvan-verantwoordelijkheid-in-de-bouw.pdf (accessed 01/08/2014).

Cormie D (2013) Manual for the Systematic Risk Assessment of High-Risk Structures Against Disproportionate Collapse. Institution of Structural Engineers, London, UK.

De Groot G (2008) Het Deskundigenadvies in de Civiele Procedure. Kluwer, Deventer, the Netherlands, pp. 13-14. (in Dutch).

Dutch Safety Board (2012a) Roof Collapse During Extension Work at the Stadium of FC Twente in Enschede, the Netherlands. Dutch Safety Board, The Hague, the Netherlands. See www. onderzoeksraad.nl/uploads/items-docs/1824/Samenvattig _ Rapport_Grolsch_Veste_EN_DEF_web.pdf (accessed 01/08/2014).

Dutch Safety Board (2012b) Instorting verdiepingsvloer B-Tower Rotterdam. Dutch Safety Board, The Hague, the Netherlands. (in Dutch). See www.onderzoeksraad.nl/uploads/items-docs/ 953/Rapport_B-Tower_NL_web.pdf (accessed 01/08/2014).

Edward Lindenberg v. Joe Canning Jerome Contracting Ltd (1992) 62 BLR 147.

Gambon S (2007) Naar een andere regeling voor aansprakelijkheid bij gebreken? Tijdschrift Bouwrecht 2007(5) (in Dutch).

Furst S and Ramsey V (2006) Keating on Building Contracts. Sweet and Maxwell, London, UK, p. 291.

Havinga T, Klaassen C and Neelis N (2012) Specialisatie Gewenst? De Behoefte aan Gespecialiseerde Rechtspraak binnen het Nederlandse Bedrijfsleven. Name of publisher, Location of Publisher, Research Memoranda, 2012/2, pp. 69-77 (in Dutch). See http://www.rechtspraak.nl/Organisatie/Publicaties-EnBrochures/Researchmemoranda/research\%20memoranda/ Specialisatie-gewenst.pdf (accessed 01/08/2014).

Helsloot I and Schmidt A (2012) Risicoaansprakelijkheid als Vervanging van Overheidstoezicht in de Bouw. Boom Lemma, The Hague, the Netherlands (in Dutch).

Hinze J (1993) Construction Contracts. McGraw-Hill, New York, USA, pp. 2-3.

Koning MA and Schep E (2012) De Bouw in 2020. Economisch Instituut voor de Bouw, Amsterdam, the Netherlands (in Dutch). See www.eib.nl/pdf/de-bouw-in-2020.pdf (accessed 01/08/2014).

Lampe PP (2007) Snel, onpartijdig en deskundig. In Honderd jaar Raad van Arbitrage voor de Bouw. Instituut voor Bouwrecht, The Hague, the Netherlands, pp. 189-190.

Lupton S (2013) Design Liability in the Construction Industry. Wiley Blackwell, Oxford, UK, pp. 123-124, 154-166, 407-408.
Luzak JA (2012) The Implied Duty of Service Provider to Warn about Risk of Construction Defects Resulting from a Contract with a Third Party, with Emphasis on Defects Resulting from Design Failures: A Case Study on the Precontractual and Contractual Duty to Warn in English, German and Dutch Law and in the Draft Common Frame of Reference. Instituut voor Bouwrecht, The Hague, the Netherlands, pp. 116-138.

Plant Construction Plc v. Clive Adams Associates and JMH Construction Services Ltd (2000) BLR 158; 69 Con LR 106 (CA).

Raad van Arbitrage voor de Bouw (2015) http://www. raadvanarbitrage.nl (accessed 31/01/2015).

Reynolds MP (2002) The Expert Witness in Construction Disputes. Blackwell Science, Oxford, UK, p. 157.

Schneider J and Matousek M (1976) Untersuchungen zur Struktur des Sicherheitsproblems bei Bauwerken. Zürich Institut für Baustatik und Konstruktion, Zürich, Switzerland.

Spekkink D (2009) Castle or House of Cards? Strengthening the Structural Safety Chain. Inspectorate of Housing, Spatial Planning and the Environment. Location of publishing organization. See http://www.rijksoverheid.nl/bestanden/ documenten-en-publicaties/rapporten/2009/05/01/castle-orhouse-of-cards-strengthening-the-structural-safety-chain/9145. pdf (accessed 01/08/2014).

Stichting Aanbestedingsinstituut Bouw and Infra (2013) Langs de Meetlat! Resultaten Aanbestedingsanalyse 2012. Zoetermeer, the Netherlands (in Dutch). See www. aanbestedingsinstituut.nl (accessed 01/08/2014).

Terwel KC (2014) Structural Safety: Study into Critical Factors in the Design and Construction Process. Ipskamp Drukkers, Enschede, the Netherlands.

Terwel KC, Boot WF and Nelisse RML (2014) Structural unsafety revealed by failure databases. Proceedings of the Institution of Civil Engineers - Forensic Engineering 167(1): 16-26, http://dx.doi.org/10.1680/feng.13.00019.

The Law Commission (2001) Limitations of Actions, 9 July 2001, p. 2.

Uff J (2002) Construction Law. Sweet and Maxwell, London, UK, pp. 214.

Van Bladel CBE (2002) Arbitrage in de Praktijk. Boom Juridische Uitgevers, Utrecht, the Netherlands (in Dutch).

Van den Berg MAMC (2013a) Mr. C. Assers Handleiding tot de beoefening van het Nederlands Burgerlijk Recht. 7. Bijzondere overeenkomsten. Deel VI. Aanneming van werk. Kluwer, Deventer, the Netherlands, pp. 191-194. (in Dutch).

Van den Berg LC (2013b) Gastcolumn: Bouwrecht en de burgerlijke rechter. Tijdschrift voor Bouwrecht 2013(12): 000-000. (in Dutch).

Van Romburgh HD (2007) Hoe een eerbiedwaardig instituut het aanbesteden op de kaart heft gezet! In Honderd jaar Raad van Arbitrage voor de Bouw. Instituut voor Bouwrecht, The Hague, the Netherlands, pp. 267-268. 
Vermeij P (2014) Enkele kritische opmerkingen over het (eind) rapport 'Naar een andere verdeling van verantwoordelijkheid in de bouw. Tijdschrift voor Bouwrecht 2014(6): 518-528.

VROM-Inspectie (2008) Wég Met de Zwakke Schakels! VROM. The Hague, the Netherlands, pp. 47 (in Dutch). See www. rijksoverheid.nl/documenten-en-publicaties/rapporten/2008/11/ 01/weg-met-de-zwakke-schakels-actieagenda-voor-deversterking-van-de-constructieve-veiligheidsketen.html (accessed 01/08/2014).

\section{WHAT DO YOU THINK?}

To discuss this paper, please submit up to 500 words to the editor at journals@ice.org.uk. Your contribution will be forwarded to the author(s) for a reply and, if considered appropriate by the editorial panel, will be published as a discussion in a future issue of the journal.

Proceedings journals rely entirely on contributions sent in by civil engineering professionals, academics and students. Papers should be 2000-5000 words long (briefing papers should be 1000-2000 words long), with adequate illustrations and references. You can submit your paper online via www.icevirtuallibrary.com/content/journals, where you will also find detailed author guidelines. 